\title{
MALDI Imaging Mass Spectrometry (MALDI-IMS)—Application of Spatial Proteomics for Ovarian Cancer Classification and Diagnosis
}

\section{Johan O. R. Gustafsson ${ }^{1}$, Martin K. Oehler ${ }^{2}$, Andrew Ruszkiewicz ${ }^{3}$, Shaun R. McColl ${ }^{1}$ and Peter Hoffmann ${ }^{1, *}$}

1 Adelaide Proteomics Centre, School of Molecular and Biomedical Science, The University of Adelaide, SA 5005, Adelaide, Australia; E-Mails: ove.gustafsson@adelaide.edu.au (J.O.R.G.); shaun.mccoll@adelaide.edu.au (S.R.M.)

2 Robinson Institute, Research Centre for Reproductive Health, School of Paediatrics and Reproductive Health, The University of Adelaide, SA 5005, Adelaide, Australia;

E-Mail: martin.oehler@adelaide.edu.au

3 Surgical Pathology, SA Pathology, Adelaide SA 5000, Australia;

E-Mail: andrew.ruszkiewicz@health.sa.gov.au

* Author to whom correspondence should be addressed; E-Mail: peter.hoffmann@ adelaide.edu.au; Tel.: +61-(08)-8303-5507; Fax: +61-(08)-0-8303-4362.

Received: 1 December 2010; in revised form: 10 January 2011 / Accepted: 17 January 2011 / Published: 21 January 2011

\begin{abstract}
MALDI imaging mass spectrometry (MALDI-IMS) allows acquisition of mass data for metabolites, lipids, peptides and proteins directly from tissue sections. IMS is typically performed either as a multiple spot profiling experiment to generate tissue specific mass profiles, or a high resolution imaging experiment where relative spatial abundance for potentially hundreds of analytes across virtually any tissue section can be measured. Crucially, imaging can be achieved without prior knowledge of tissue composition and without the use of antibodies. In effect MALDI-IMS allows generation of molecular data which complement and expand upon the information provided by histology including immuno-histochemistry, making its application valuable to both cancer biomarker research and diagnostics. The current state of MALDI-IMS, key biological applications to ovarian cancer research and practical considerations for analysis of peptides and proteins on ovarian tissue are presented in this review.
\end{abstract}

Keywords: MALDI; imaging; mass spectrometry; ovarian cancer; grading; biomarker 


\section{Epidemiology of Ovarian Cancer}

In 2010, an estimated 21880 new cases of ovarian cancer will be diagnosed in the USA [1]. http://www.cancer.org/research/cancerfactsfigures/cancerfactsfigures/cancer-facts-and-figures-2010.

With a projected 13850 deaths from this disease in 2010, ovarian cancer has the highest mortality rate of all gynaecological malignancies. The high mortality from ovarian cancer is due to the majority of patients (64\%, see Table 1) being diagnosed with advanced (International Federation of Gynecology and Obstetrics (FIGO) stage III + IV) disease, which has a maximum 5-year survival of only 30\% [2]. In contrast, the 5-year survival for patients with organ-confined FIGO stage I ovarian cancer exceeds $90 \%$ and a large number of these patients are cured. Thus, early detection is the key to increased survival in ovarian cancer.

Table 1. FIGO ovarian cancer stages, prevalences and anatomical features.

\begin{tabular}{|c|c|c|}
\hline FIGO Stage & Prevalence (\%) & Anatomical features \\
\hline I & 25 & Limited to ovaries \\
\hline II & 11 & Pelvic extension \\
\hline III & 47 & Abdominal extension and/or positive lymph nodes \\
\hline IV & 17 & Distant metastases \\
\hline
\end{tabular}

\section{Early Detection of Ovarian Cancer}

While other gynaecological cancers can be diagnosed at an early stage due to effective screening (e.g., PAP smear in the case of cervical cancer) or symptoms (e.g., bleeding in the case of endometrial cancer), neither specific early disease symptoms or an early detection test exist for ovarian cancer. Presently, diagnosis involves a combination of physical examination, followed by trans-vaginal ultrasound, measurement of serum levels of the glycoprotein CA-125 and exploratory surgery if a suspicious ovarian lesion has been identified [1]. CA-125, when combined with ultrasound, has a positive predictive value (PPV) of only $35.1 \%$ for primary EOCs [2]. This low PPV indicates that two out of every three patients will be over diagnosed and undergo unnecessary and potentially harmful invasive procedures. Novel biomarkers are therefore required to improve ovarian cancer detection.

Single markers, such as CA125, are unlikely to provide the sensitivity and specificity required for ovarian cancer screening [3]. The focus has thus shifted to panels of biomarkers, which for the moment are additional diagnostic tools, not screening options [4,5]. Further improvements to these panels require not only discovery of new biomarkers, but also validation of existing biomarker candidates. Moreover, the large numbers of newly identified potential biomarkers have to be validated individually in a large cohort of patients, which is currently impractical. The use of serum or plasma for many biomarker discovery projects also complicates the process of biomarker discovery, as serum has a high protein complexity, large dynamic range of protein concentration $\left(10^{12}\right)$ [6] and contains non-specific acute phase proteins. A more promising approach is therefore the direct analysis of the cancer tissue, as it should have the highest concentration of disease specific markers [7] and a smaller dynamic range of protein concentration $\left(10^{6}\right)$ [8]. Thus, by focusing on tissue identified candidates it should be possible to compile a smaller subset of biomarkers with a higher specificity which can be validated in situ by immuno-histochemistry (IHC) and subsequently in large patient cohorts by established methods 
like enzyme linked immuno-sorbent assays (ELISA). These biomarkers could then be used in novel high specificity panels for early diagnosis of ovarian cancer.

\section{Molecular Classification of Ovarian Carcinomas}

The absence of reliable biomarkers is not the only issue with respect to ovarian cancer diagnosis. Following histologic confirmation of ovarian disease, treatment is assigned based upon stage [1]. Ovarian cancer staging is currently defined by the FIGO classification system for tumour dissemination into extra-ovarian sites (see Table 1), which correlates well with patient five year survival (see SEER http://seer.cancer.gov/statfacts/html/ovary.html)[9,10]. However, grade is an additional important prognostic parameter [11]. Grade, as determined by light microscopy describes morphological characteristics of tumour tissue including percentage of solid growth, architecture, nuclear features and mitotic activity (see Table 2). [12]. These characteristics are subjective and their reproducibility may be suboptimal [12]. Moreover, contention exists as to which grading systems most accurately reflect ovarian tumour differentiation status and therefore optimal treatment $[12,13]$.

Table 2. Grading systems for epithelial ovarian carcinoma: FIGO, universal three tier grading and two tier grading.

\begin{tabular}{|c|c|c|c|c|c|c|}
\hline \multicolumn{2}{|c|}{ Grading system } & Grade & \multicolumn{3}{|c|}{ Key features } & Ref. \\
\hline \multirow{3}{*}{\multicolumn{2}{|c|}{ FIGO }} & 1 & Well differentiated & & $<5 \%$ solid growth & \multirow[b]{2}{*}{ [10] } \\
\hline & & 2 & $\begin{array}{c}\text { Moderately } \\
\text { differentiated }\end{array}$ & \multirow{2}{*}{$\begin{array}{l}\text { solid non-squamous } \\
\text { growth, grade }+1 \text { if } \\
\text { nuclear atypia apparent }\end{array}$} & $6-50 \%$ solid growth & \\
\hline & & 3 & Poorly differentiated & & $>50 \%$ solid growth & \multirow[b]{2}{*}{ [13] } \\
\hline \multirow{3}{*}{\multicolumn{2}{|c|}{$\begin{array}{l}\text { 3-tier universal } \\
\text { grading }\end{array}$}} & 1 & \multirow{3}{*}{$\begin{array}{l}\text { Grade based on sum } \\
\text { of individual feature } \\
\text { scores (see right) } \\
\begin{aligned} 1=3-5 \text { points } \\
2=6-7 \text { points } \\
3=8-9 \text { points }\end{aligned}\end{array}$} & $\begin{array}{l}\text { Architecture based } \\
\text { score }\end{array}$ & $\begin{array}{c}\text { Glandular }=1 \text { point } \\
\text { Papillary }=2 \text { points } \\
\text { Solid }=3 \text { points }\end{array}$ & \\
\hline & & 2 & & $\begin{array}{l}\text { Nuclear pleomorphism } \\
\text { score }\end{array}$ & $\begin{array}{c}\text { Slight }=1 \text { point } \\
\text { Moderate }=2 \text { points } \\
\text { Marked }=3 \text { points }\end{array}$ & \multirow{2}{*}[12]{} \\
\hline & & 3 & & Mitotic activity score & $\begin{array}{c}0-9=1 \text { point } \\
10-24=2 \text { points } \\
\geq 25=3 \text { points }\end{array}$ & \\
\hline \multirow{4}{*}{$\begin{array}{l}\text { 2-tier } \\
\text { grading }\end{array}$} & \multirow{2}{*}{$\begin{array}{l}\text { Serous } \\
\text { tumour }\end{array}$} & $\begin{array}{l}\text { Low grade } \\
\text { (type I) }\end{array}$ & Slow development & $\begin{array}{c}\text { Low chromosomal } \\
\text { instability }\end{array}$ & $\begin{array}{c}\text { Gene mutation- } \\
\text { KRAS, BRAF, ERBB2 }\end{array}$ & \multirow{2}{*}[14]{} \\
\hline & & $\begin{array}{c}\text { High grade } \\
\text { (type II) }\end{array}$ & Rapid development & $\begin{array}{l}\text { High chromosomal } \\
\text { instability }\end{array}$ & Gene mutation-P53 & \\
\hline & \multirow[b]{2}{*}{$\begin{array}{l}\text { Endomet } \\
\text { roid } \\
\text { tumour }\end{array}$} & Low grade & $\begin{array}{c}\text { Well differentiated, } \\
\text { no necrosis }\end{array}$ & $\begin{array}{c}\text { Solid glandular } \\
\text { architecture }\end{array}$ & $\begin{array}{c}\text { Gene mutation-Wnt, } \\
\text { PI3K/Akt }\end{array}$ & {$[13]$} \\
\hline & & High grade & $\begin{array}{c}\text { Solid growth }>50 \%, \\
\text { necrosis }\end{array}$ & $\begin{array}{l}\text { Diffusely infiltrative } \\
\text { or expansive growth, } \\
\text { no glandular } \\
\text { architecture }\end{array}$ & Gene mutation-TP53 & {$[16]$} \\
\hline
\end{tabular}

Based on recent advances in the understanding of the molecular biology of ovarian cancer it is now believed that the major ovarian cancer subtypes can be separated (see Table 2) into type I (low grade) or type II (high grade) based upon differential gene and/or protein expression [13-16]. These 
two-tiered molecular systems of ovarian cancer grading provide an avenue for defining cancer differentiation state in absolute terms. As such, molecular grading systems need to be developed to a point where they can complement routine histo-pathological examination of ovarian cancer tissue. Importantly, this also needs to be achieved on a similar time scale to histology, in this case one to two hours.

Thus, to improve EOC management and outcome for patients, both discovery of novel, effective biomarkers and development of a new molecular grading/classification system are required.

\section{Application of Proteomics to Ovarian Cancer}

Although gene expression is useful for distinguishing ovarian tumour subtypes [14], it does not always correlate with protein translation $[17,18]$, nor can levels of post translational modification (PTM) be directly inferred from genetic analyses [19]. However, both protein expression level and PTM state have drastic effects on cellular function/dysfunction and as a result it is more meaningful to analyse the disease-related proteins and peptides. Generating protein profiles with sufficient molecular features is impossible with IHC, as it is limited to a maximum of three to four antibodies at a time and, crucially, depends on antibody quality. Proteomics, however, allows analysis of hundreds to thousands of peptide and protein features in biological samples [20], in many cases without the need for antibodies.

The term "proteomics" was coined to describe the quantitative analysis of the proteome, which represents all proteins expressed in a given cell, tissue (e.g., cancer) or biological fluid (e.g., serum) at a given point in time or under the effects of a defined biological stimulus [21]. High analytical sensitivity is achieved in proteomics because complex protein mixtures are fractionated following tissue or cell lysis (disruption), followed by further purification or direct analysis by mass spectrometry (MS) [22,23]. These methods allow for identification of thousands of proteins from a single cell lysate. For example, two separate studies from 2006 [24] and 2008 [19] demonstrated profiling of ovarian cancer subtypes using liquid chromatography (LC) separation followed by MS (LC-MS). The 2008 study showed that early and late stage endometroid ovarian carcinoma MS profiles can be distinguished using a clustering analysis, which separates profiles based on feature similarity; in this case similar protein masses [19]. Importantly, the 2008 publication also combined profiling MS data for serous and clear cell tumours from the 2006 study [24] to show that the three subtypes grouped separately in a principal component analysis (PCA). These studies are significant as they indicate that "classical" proteomics can generate molecular fingerprints of disease. However, there are two issues for implementing proteomics in this manner. Firstly, tissue disruption for analysis removes spatial proteome information, which is critical for clinical application, especially in heterogeneous carcinomas where different structural elements will express a unique proteome with subsequent unique cellular function. A common method for addressing this problem is laser capture micro-dissection (LCM) [7], which can isolate specific cell populations for analysis. However, similar to many proteomics methods, including liquid phase separation, LCM is time consuming. The second issue is thus that a proteomic method is required that can be implemented in the same time frame as classical histology (i.e., one to two hours). 


\section{Tissue Analysis by Mass Spectrometry}

Direct tissue section analysis utilising an MS instrument removes the need for disruption and the subsequent loss of spatial proteome information. This approach also provides an avenue for molecular classification/grading because tissue sections can be prepared and analysed rapidly (1-3 hours) using standardised protocols. Importantly, tissue specific biomarkers can be visualised and subsequently identified using "classical" proteomics methods such as LC-MS. For easy reference, the advantages and disadvantages of methods for analysing tissues (histology, IHC and proteomics) are summarised in Table 3.

Table 3. Comparison of different methods (histology, immuno-histochemistry (IHC) and proteomics (fractionation coupled to mass spectrometry (MS) and direct tissue MS) for peptide/protein analysis in tissue samples.

\begin{tabular}{|c|c|c|c|c|}
\hline & \multirow{2}{*}{ Histology } & \multirow{2}{*}{ IHC } & \multicolumn{2}{|c|}{ Proteomics } \\
\hline & & & Fractionation-MS & Direct tissue MS \\
\hline Methods & Cellular staining & $\begin{array}{l}\text { Antibody directed } \\
\text { staining of specific } \\
\text { proteins }\end{array}$ & $\begin{array}{c}\text { Liquid phase separation } \\
\text { (i.e., liquid } \\
\text { chromatography) }\end{array}$ & $\begin{array}{c}\text { Direct measurement of } \\
\text { peptides and proteins from } \\
\text { tissue section }\end{array}$ \\
\hline \multirow[b]{2}{*}{ Analysis } & \multirow{2}{*}{$\begin{array}{l}\text { Tissue morphology } \\
\text { assessment by light } \\
\text { microscopy }\end{array}$} & \multirow{2}{*}{$\begin{array}{l}\text { Protein distribution } \\
\text { across tissue } \\
\text { sections }\end{array}$} & $\begin{array}{c}\text { MS protein } \\
\text { identification }\end{array}$ & $\begin{array}{c}\text { MS profiles of tissue } \\
\text { sections }\end{array}$ \\
\hline & & & $\begin{array}{l}\text { Quantitation using } \\
\text { protein labelling }\end{array}$ & $\begin{array}{l}\text { Peptide and protein intensity } \\
\text { maps showing distribution } \\
\text { across tissue sections }\end{array}$ \\
\hline \multirow{4}{*}{ Advantages } & $\begin{array}{c}\text { Easy staining } \\
\text { methods }\end{array}$ & Highly specific & Highly sensitive & Rapid \\
\hline & $\begin{array}{c}\text { Cellular microscopy } \\
\text { resolution }\end{array}$ & $\begin{array}{c}\text { Cellular microscopy } \\
\text { resolution }\end{array}$ & $\begin{array}{l}\text { Thousands of proteins } \\
\text { analysed at a time }\end{array}$ & $\begin{array}{l}\text { Spatial proteome } \\
\text { information }\end{array}$ \\
\hline & Well established & Well established & Heavily automated & $\begin{array}{l}\text { Measurement of hundreds of } \\
\text { molecular features at a time }\end{array}$ \\
\hline & $\begin{array}{l}\text { Clinical personnel } \\
\text { already available }\end{array}$ & $\begin{array}{l}\text { Clinical personnel } \\
\text { already available }\end{array}$ & $\begin{array}{l}\text { Highly modular } \\
\text { workflows }\end{array}$ & No antibodies required \\
\hline \multirow{4}{*}{ Disadvantages } & $\begin{array}{c}\text { Reproducibility } \\
\text { issues }\end{array}$ & Time consuming & Time consuming & Expensive equipment \\
\hline & $\begin{array}{l}\text { Based on visual } \\
\text { assessment of } \\
\text { morphology }\end{array}$ & Labor intensive & Labor intensive & Novel technology \\
\hline & Non-specific & $\begin{array}{l}\text { Limited to 3-4 } \\
\text { proteins }\end{array}$ & $\begin{array}{l}\text { Removes spatial } \\
\text { information }\end{array}$ & $\begin{array}{c}\text { Requires fraction-MS based } \\
\text { proteomics to identify } \\
\text { peptide and protein features }\end{array}$ \\
\hline & $\begin{array}{l}\text { Analysis is } \\
\text { subjective }\end{array}$ & $\begin{array}{l}\text { Dependent on } \\
\text { antibody quality }\end{array}$ & $\begin{array}{l}\text { Requires specialist } \\
\text { personnel }\end{array}$ & $\begin{array}{l}\text { Analytical resolution limited } \\
\text { to a maximum of } 20-50 \mu \mathrm{m}\end{array}$ \\
\hline
\end{tabular}

MS measurement of molecules directly from tissue was first described in 1997 [25]. MS instruments measure the mass to charge ratio $(\mathrm{m} / \mathrm{z})$ of gaseous ions, in this case peptide or protein ions. Mass is of value because it indicates composition, which, for example, can be used to identify proteins 
of interest by their component peptides. To generate ions directly from tissue, either secondary ion MS (SIMS) or matrix-assisted laser desorption/ionisation (MALDI) instruments are utilised.

SIMS utilises the impact of an ion beam (e.g., $\mathrm{Ar}^{+}$or $\mathrm{Ga}^{+}$) to induce a localised gain in kinetic energy on the tissue surface. Once a sufficient energy level is reached secondary ions (e.g., peptides) are ejected from the tissue for mass measurement [26]. In practice, SIMS causes surface fragmentation and as a result limits measurement to metabolites, lipids and small peptides ( $<1000 \mathrm{Da})$ [26].

MALDI represents a more suitable ionisation method for direct application to tissue. Preparation for MALDI requires a tissue section to be coated with a low molecular weight organic molecule, called the "matrix". The most common matrix compounds, 2,5-dihydroxybenoic acid (DHB), a-cyano-4-hydroxycinnamic acid (CHCA), and sinapinic acid (SA) are listed in Table 4 along with example modifications made to the matrix composition, their full chemical names and bio-molecule specificity. Several of these matrix combinations have been applied to ovarian tissue including DHB/3-AP [27], CHCA [28], CHCA/ANI [28], SA [28,29], SA/3-AP [30] and SA/HFIP [30,31]. Most matrixes are dissolved in a 50-60\% acidified organic solvent solution, which extracts lipids, peptides and proteins from the tissue prior to evaporation, allowing the matrix to crystallise. The end result is a field of sample-matrix co-crystals on the tissue surface.

Table 4. List of the three most common matrix types-2,5-dihydroxybenzoic acid (DHB), $\alpha$-cyano-4-hydroxycinnamic acid (CHCA) and 3,5-dimethoxy-4-hydroxycinnamic acid (sinapinic acid, SA) as well as their documented modifications - for MALDI mass spectrometry. Suitability for measurement of bio-molecules is specified [26].

\begin{tabular}{|l|l|l|}
\hline Matrix & Chemical name & Biomolecule specificity \\
\hline DHB & 2,5-dihydroxybenzoic acid & Lipids, peptides, $<10 \mathrm{kDa}$ proteins \\
\hline DHB/aniline & DHB + aniline & Lipids, peptides, $<10 \mathrm{kDa}$ proteins \\
\hline DHB/3-AP & DHB + 3-acetyl pyridine & Lipids, peptides, $<10 \mathrm{kDa}$ proteins \\
\hline CHCA & $\alpha$-cyano-4-hydroxycinnamic acid & Peptides, small proteins $(<10 \mathrm{kDa})$ \\
\hline CHCA/aniline & CHCA + aniline & Peptides, $<10 \mathrm{kDa}$ proteins \\
\hline SA & 3,5-dimethoxy-4-hydroxycinnamic acid & Proteins $(>10 \mathrm{kDa})$ \\
\hline SA/aniline & SA + aniline & Proteins $(>10 \mathrm{kDa})$ \\
\hline SA/3-AP & SA +3 -acetyl pyridine & Proteins $(>10 \mathrm{kDa})$ \\
\hline SA/HFIP & SA $+1,1,1,3,3,3$-hexafluoro-2-propanol & Proteins $(>30 \mathrm{kDa})$ \\
\hline SA/TFE & SA $+2,2,2$-trifluoroethanol & Proteins $(>30 \mathrm{kDa})$ \\
\hline
\end{tabular}

MALDI is achieved by directing a laser beam at the co-crystals. The matrix absorbs the bulk of incident laser energy, causing an explosive transition from solid crystal to a gaseous plume, during which ionisation of the sample occurs (see Figure 1) [32-35]. MALDI is suited to bio-molecule analysis because it is a "soft" ionisation process, in that the matrix is the energy absorber, minimising protein/peptide fragmentation. MALDI ion sources are typically coupled to time-of-flight (TOF) mass analysers. Ions from the MALDI process are accelerated into the TOF tube, which is an electric field free flight region. The kinetic energy gained during acceleration decreases with increasing mass and as such heavier ions will fly slower and therefore have a longer time-of-flight. This is the basis of TOF mass analysis. When an ion hits an attached detector, the time from laser ionisation to detection is used to derive $\mathrm{m} / \mathrm{z}$ (see Figure 1). The end result is a plot of $\mathrm{m} / \mathrm{z}$ against intensity (ion counts); commonly 
referred to as an MS spectrum. The preference of most groups for MALDI-TOF instruments is due to their sensitivity (femto to attomolar range under ideal conditions), ease of use and achievable mass range of MALDI-TOF, which reaches from small molecules (100 Da) to large proteins (>300 $\mathrm{kDa})$, allowing measurement of metabolites, lipids, peptides and proteins on the same instrument.

Figure 1. Basic principles of matrix-assisted laser desorption/ionisation (MALDI) time-offlight (TOF) mass spectrometry. Following ionisation, sample ions are accelerated into an electric field free "drift" region. The larger the ion the less energy it will gain during acceleration and as a result it will travel slower than smaller ions. This is the basis of time of flight separation. Time from laser ionisation to detection at the opposite end of the drift region is used to determine mass to charge ratio $(\mathrm{m} / \mathrm{z})$ for masses between $0-300 \mathrm{kDa}$. High mass accuracy is achieved using a reflector field that focuses ions from $0-6 \mathrm{kDa}$ onto a secondary detector.

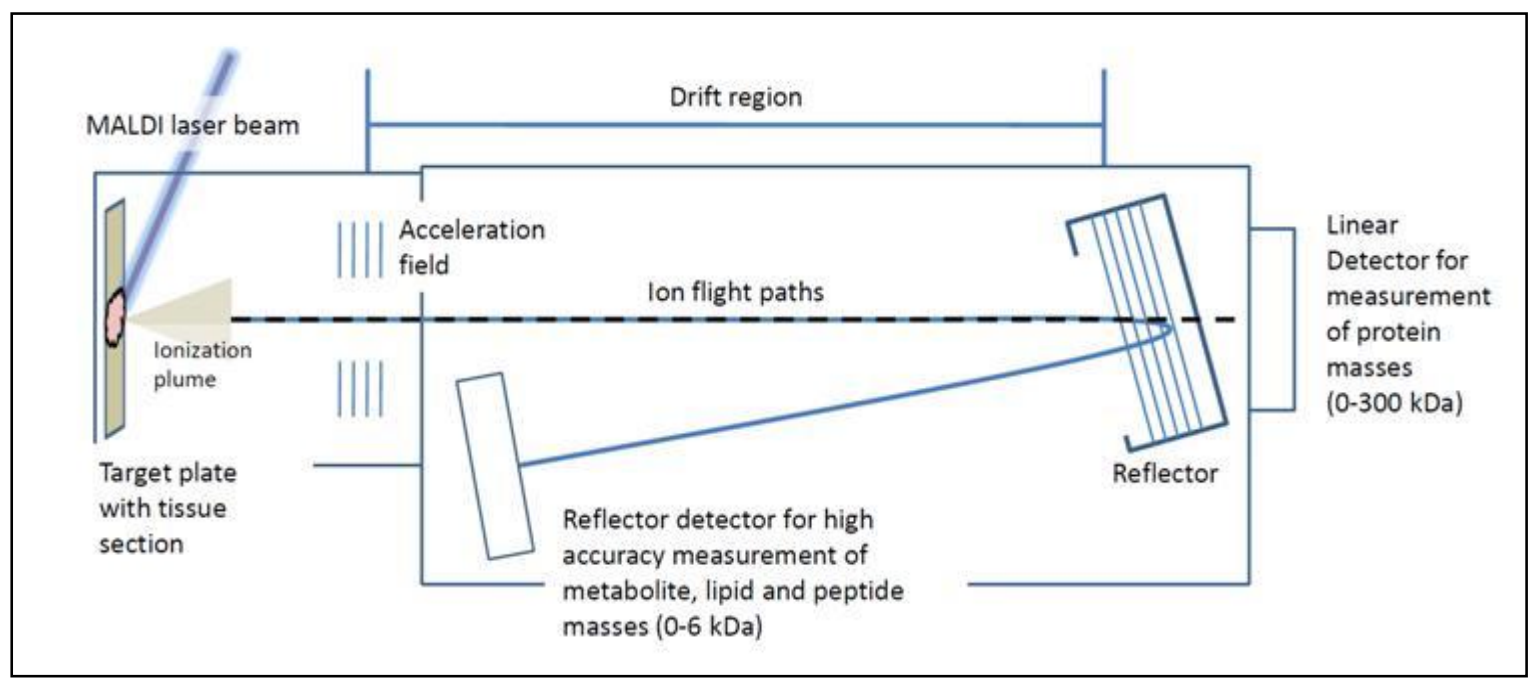

The key advantages of MALDI-TOF MS application directly to tissue are thus that:

(i) Several bio-molecule classes from different mass ranges can be measured, including drugs [36], lipids [27], peptides [37,38] and proteins [31,39,40].

(ii) Several hundred molecular features can be measured in a single experiment (see Figure $3 a-c$ ).

(iii) No preliminary knowledge about tissue composition is required.

(iv) No antibodies are required.

\section{Methods for in Situ MALDI-TOF Analysis of Ovarian Cancer Tissue}

An outline of the methodology for in situ MS analysis of ovarian tissue is shown in Figure 2. Sectioned tissue $(2-10 \mu \mathrm{m}$ thick) is mounted directly onto chilled conductive glass slides (indium tin oxide coated) or metallic targets (e.g., gold coated target). The mounted sections are dried (15-45 min) before fixation with a graded alcohol series $(70 \%$ and $100 \% \mathrm{v} / \mathrm{v}$ ethanol/isopropanol) or organic solvents such as chloroform or acetone [41-44]. This fixation has been shown to increase the quality of MS signals, most likely as a result of physiological salt and lipid removal, both of which interfere with matrix crystallisation and subsequent quality of MS data [42,43]. For ovarian tissue, washes with $70 \%$ 
and $100 \%$ isopropanol are sufficient to generate rich small protein (Figure 3a) and endogenous peptide (Figure 3b) MS signals directly from carcinoma sections. However, chloroform can also be used quite successfully as a stand-alone wash prior to analysis [30]. As described previously, to allow MALDI measurement, the tissue is coated with a matrix solution. The method of matrix coating is important as it affects the type (single spectra or multiple) and quality (MS sensitivity) of data obtained. These methods are discussed further as they pertain to the two types of in situ MALDI-TOF MS experiment, profiling and imaging MS (IMS).

Figure 2. The top panel shows a typical workflow for IMS on ovarian tissue. Note the optional tryptic digest (absolute requirement for formalin-fixed paraffin embedded (FFPE) tissue). Antigen retrieval can also be used to partially hydrolyse formalin-induced protein cross-links. The bottom panel shows the two analysis workflows possible for an IMS experiment, profiling and imaging.

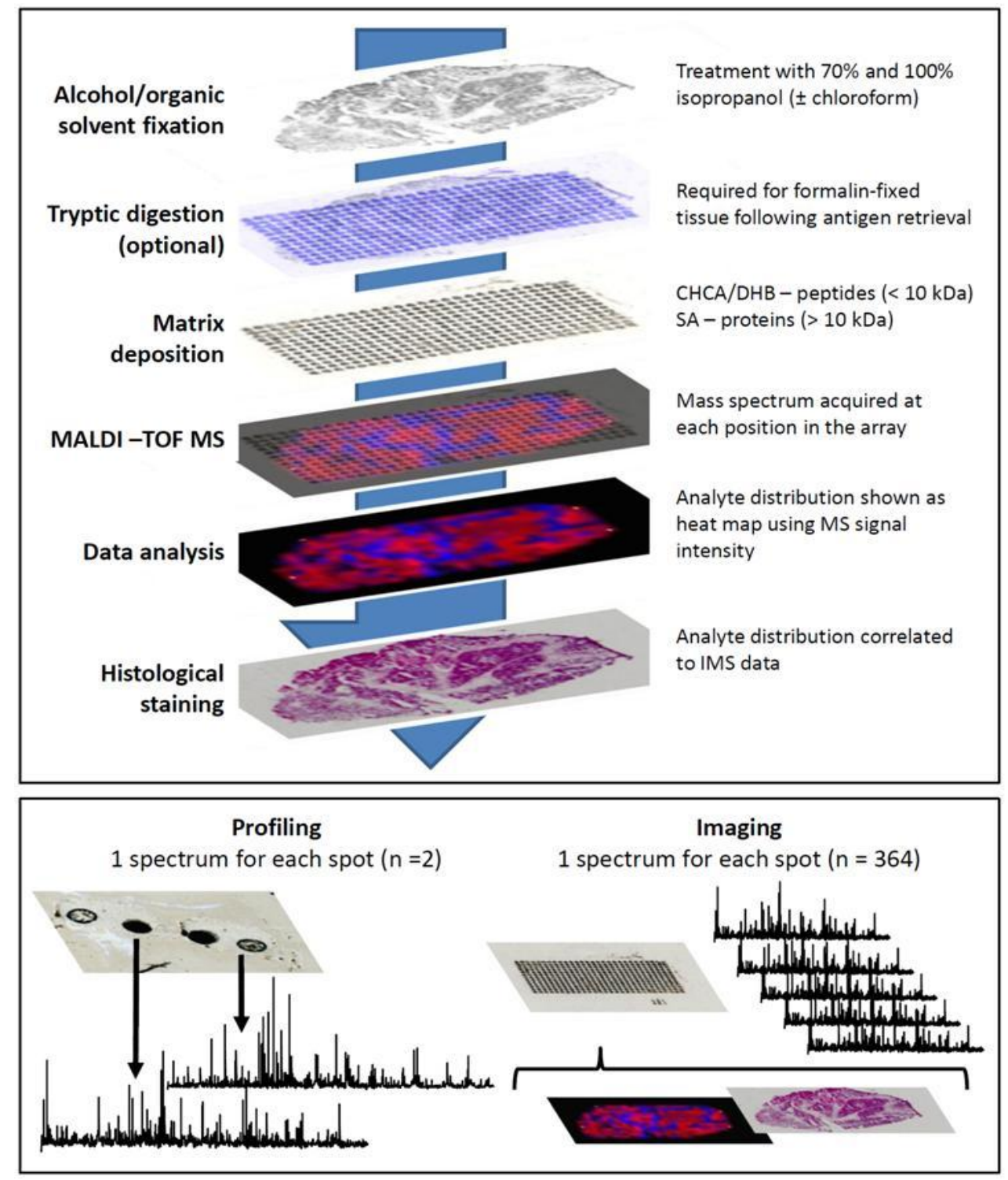


Figure 3. Data from printed arrays on stage IIIC ovarian epithelial carcinoma. The spectra in a-d represent the sum of all spectra for small protein (a-matrix only + peptide/ small protein mass range), endogenous peptide (b-matrix only + peptide mass range) and tryptic peptide (c-trypsin digestion + matrix with peptide mass range) analysis using a MALDI-TOF/TOF MS instrument. Twenty $\mathrm{mg} / \mathrm{mL}$ DHB in $50 \%$ methanol and $0.2 \%$ trifluoroacetic acid was used as a matrix. Trypsin was used at $40 \mathrm{ng} / \mu \mathrm{L}$ in a $5 \mathrm{mM}$ $\mathrm{NH}_{4} \mathrm{HCO}_{3}$ and $12 \%$ acetonitrile buffer at $\mathrm{pH} \sim 8.5$. Panel $\mathrm{d}$ shows two morphologically different areas on a H\&E stained section (green/red outlines), previously analysed by tryptic peptide IMS. Three ion intensity maps with associated spectra for the green and red areas show differential peptide distribution.

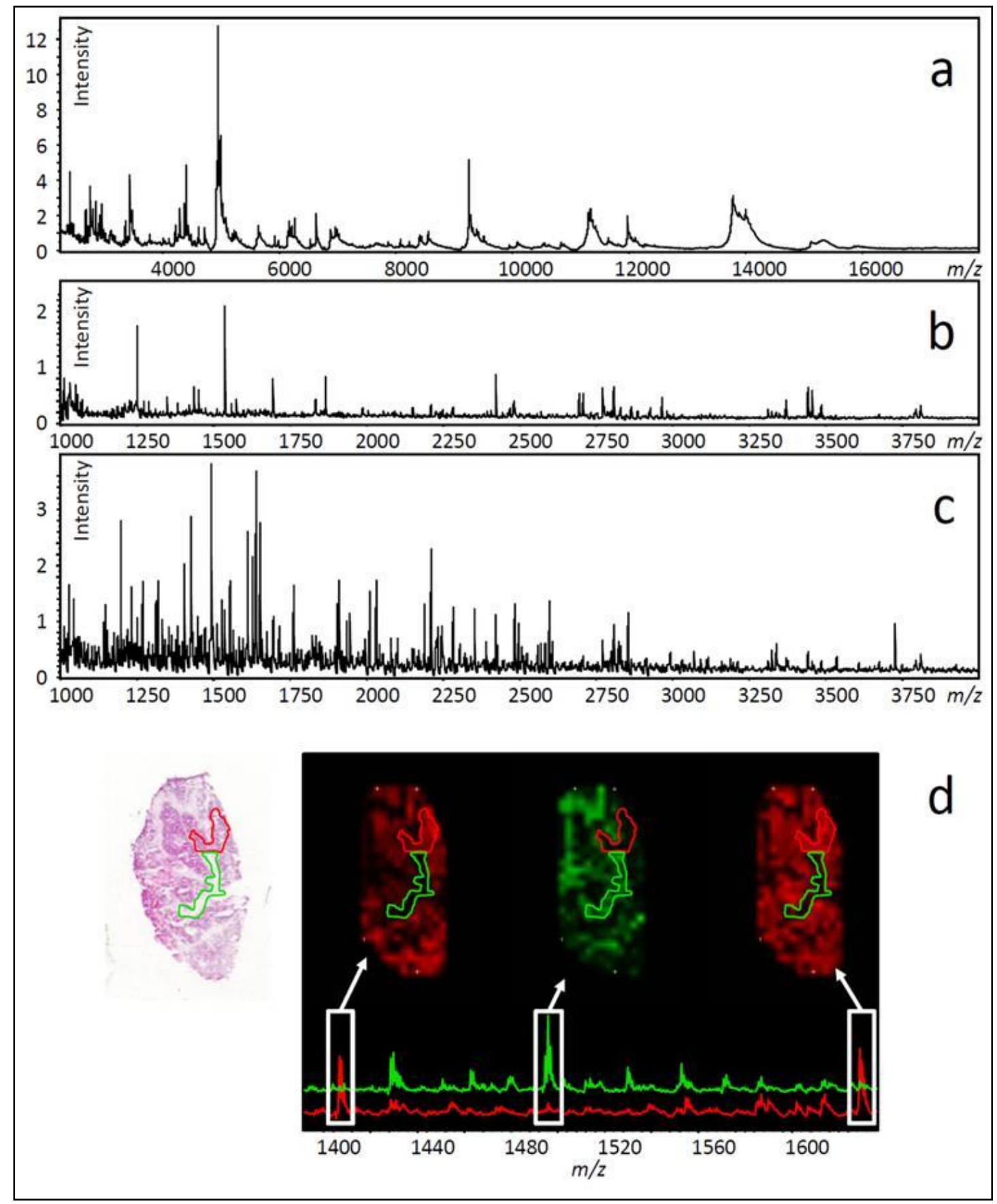




\section{Profiling Cancer Tissues Using MALDI-TOF MS}

Typically, in situ MS methods are split into two types of workflows, these being profiling MS or IMS (see Figure 2, bottom panel). The profiling MS approach uses manual or automated deposition of matrix at discrete locations on a tissue section. MS spectra are then acquired from these positions and compared. If tissue MS profiles are known from previous analyses, the same tissue type can be identified in future studies based on this profile, a process similar to the MALDI Biotyper platform used for identification of micro-organisms [45]. Because of the novelty of IMS research, there are few publications dealing exclusively with ovarian cancer. However, successful examples of molecular classification/grading have been published for non-small cell lung cancer (NSCLC) [46] and soft tissue sarcomas (STS) [47]. In the lung cancer study, $100 \mathrm{~nL}$ of sinapinic acid (SA, see Table 4) matrix was manually spotted onto 42 NSCLC tumours (>70\% tumour cellularity) and 8 normal lung sections. MS data was acquired in a $m / z$ range of $2-25 \mathrm{kDa}$ on a MALDI-TOF MS system and 82 peaks specific to the cancerous tissue were selected for development of a class prediction model. The training model generated was applied to a validation set of 32 tumour and 5 normal lung sections. Based on the MS data all 32 tumours of the validation set were classified correctly as tumour or normal. Moreover, segregation of these mass signals based on tumour subtype, in this case 14 adenocarcinoma, 15 squamous cell carcinoma and 5 large cell carcinoma, allowed for $100 \%$ separation of adenocarcinomas and squamous cell as well as squamous and large cell tumours. Only one large cell tumour was mis-classified as adenocarcinoma in the study [46]. The STS study was able to distinguish low and high grade STS using MALDI IMS profiling. Drops of SA matrix (200 nL) were applied directly to areas showing cellular proliferation following MALDI-compatible cresyl violet staining $[47,48]$. It was determined that calgizzarin (S100 A11), calcyclin, macrophage inhibitory factor and calgranulin were potentially diagnostic for high grade STS, with key extracellular proteins such as myosin being down-regulated in both low and high grade tumours as compared to control muscle tissue. These findings were confirmed using IHC against sections of tumour and control tissue [47].

In addition, pilot experiments have been published for grading follicular lymphoma [49], detection of pre-invasive bronchial lesions [50] and prostate cancer [51,52], classification of meningiomas [53], and generation of prognostic information for gliomas [54]. These pilot studies have shown the utility of characterising disease via direct MS tissue section analysis to gain diagnostic [47] and prognostic data [54].

The most comprehensive study to date analysing EOC [30] profiled tissue from 19 ovarian tumours (10 benign, 6 carcinoma and 3 borderline). Three mass ranges were examined, combining data from typical IMS peptide (CHCA matrix, see Table 4) and small protein (SA matrix) analysis with a novel method for extracting high molecular weight proteins using SA dissolved in 1,1,1,3,3,3-Hexafluoro-2propanol (HFIP). Using stage III and IV tumours, as compared to benign tissue, it was possible to profile masses matching those of cancerous marker proteins previously identified in EOC, including tetranectin $(17.7 \mathrm{kDa})$ and urokinase plasminogen activator $(36.9 \mathrm{kDa})$ [30]. Figure 4 highlights the differences between tissues as a plot of $\mathrm{m} / \mathrm{z}$ against sample number as well as a PCA loadings plot showing separation of the benign, carcinoma and borderline tissues. 
Figure 4. Figure from El Ayed et al. 2010 showing MALDI-TOF MS profiling on three classes of ovarian tissue (adenocarcinoma, borderline and benign). Plots of $\mathrm{m} / \mathrm{z}$ against spectral source as well as loadings plots from principal component analysis are included for high mass proteins (A), small proteins (B) and peptides (C). Figure reprinted, with permission, from El Ayed et al. 2010 [30].

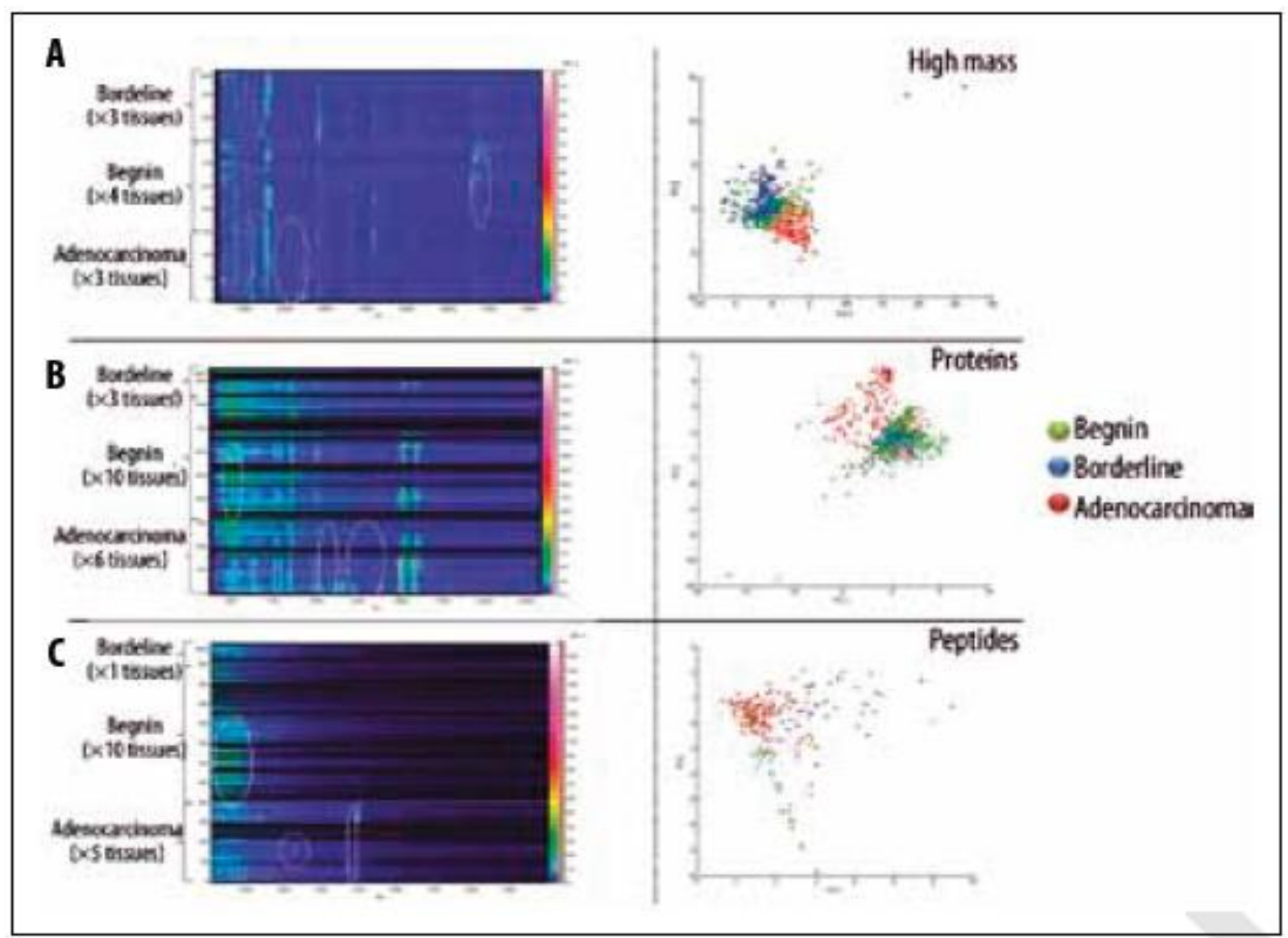

\section{Profiling vs. Imaging}

Sample preparation for profiling involves deposition of larger (100-500 nL) drops of matrix onto discrete positions of the tissue section. In contrast, IMS methods require nebulisation of a homogeneous layer of matrix or deposition of a rectangular array of smaller droplets $(0.1-0.2 \mathrm{~nL})$ onto tissue sections (Figure 2, bottom panel). The benefit of IMS is that instead of documenting profiles for singular locations, the relative abundance (based on MS signal intensity) of hundreds of protein or peptide ions is mapped across an entire tissue section at a centre to centre acquisition distance of $250 \mu \mathrm{m}$ or smaller. This is achieved by combining all spectra, acquired from a matrix array coating a single tissue section, into a sum spectrum. Mass filters are applied to the sum spectrum, which subsequently mines data from the individual spectra in the data set, presenting the normalised intensity of individual mass ranges as a 2-D heat map (see Figure 3d). It is this heat map, otherwise known as an ion intensity map, which allows visualisation of peptide and protein distribution across a tissue section. It is thus possible to document changing molecular profiles as tissue composition changes, a process which can be likened to molecular histology [55]. 


\section{Software for Data Analysis}

Several software platforms are currently available, which generate ion intensity maps from spatially referenced IMS data. A selection of IMS software platforms that were available as of 2008 were listed in Jardin-Mathe et al. (2008) [56] along with important features. Most vendors offer IMS software packages for their MS instruments, including Shimadzu Biotechnology (Intensity Mapping software), AB-SCIEX (TissueView software), Bruker Daltonics (flexImaging software), Waters (conversion tool to use BioMAP) and Thermo Fisher Scientific (ImageQuest software).

Additional freeware programs available include Novartis BioMap, data cube explorer (AMOLF, Amsterdam, Netherlands), fxSpectViewer (CEA, Saclay, France), Mirion (Justus Liebig University, Giessen, Germany) and the MALDI imaging team imaging computing system (MITICS, Lille, France) [56]. Of the mentioned software, only BioMap and data cube explorer are readily available by download. Data cube explorer, for example, uses a universal IMS file format "imzML" to avoid problems with file compatibility for newly developed software. ImzML, is based on the proteomics standard mzML [57] and is currently being proposed as a global IMS standard because it maintains the spatial coordinate system of IMS data in a universally recognisable format; in this case a smaller file for meta data and a larger binary file for the MS data (see http://www.maldi-msi.org/ and Römpp et al. (2011) [58]). The widespread use of imzML would allow IMS researchers to directly access publicly available datasets, compare data sets to their own, and compile analysis scripts to accompany published data. Both BioMap and data cube explorer are available for download from http://www.maldi-msi.org/, along with tutorials on usage.

\section{Automated Sample Preparation for Imaging Cancer Tissues}

IMS matrix deposition can be achieved using manual deposition of dry matrix powder via a sieve or sublimation, nebulising instruments such as handheld air brushes [55] and the Bruker Daltonics ImagePrep station [39], or printers such as the Labcyte Portrait [59] and Shimadzu Chemical Inkjet Printer (ChIP-1000) [60]. Table 5 summarises important features, advantages and disadvantages of the four most common matrix deposition methods. Similar to matrix choice, deposition method can also be bio-molecule specific. For example, dry deposition or sublimation of matrix leads to poor incorporation of larger molecules such as peptides and proteins into matrix crystals because there is no extracting solvent. As a result this type of deposition is typically employed for IMS of metabolites and lipids, which have a higher ionisation efficiency. The air brush and ImagePrep station are more efficient in terms of sample incorporation into the matrix crystals and are suitable for all bio-molecule types (optimisation of methods may be necessary). However, only experienced users should attempt air brush deposition of matrix, as volume, flow and subsequently reproducibility are difficult to control (see Table 5). Greater control is possible for nebulisation using the ImagePrep, where matrix solution is gravity fed onto a porous metal film, which is vibrated by current flow through an attached piezoelectric sheet. As a result, the matrix is vaporized (nebulised) and settles as a dense mist onto the tissue section. Matrix deposition in the ImagePrep is controlled by measurement of light scatter, which increases with greater crystal density. These nebulised preparations generate a homogeneous matrix field where the spatial acquisition resolution is usually limited to $20-50 \mu \mathrm{m}$ for the homogeneous 
matrixes (CHCA and SA, see Table 4), although higher resolution work has been reported for manual spray preparations [55]. A steady loss of MS sensitivity (i.e., ion count intensity) is experienced as resolution is increased, as a result of the smaller area and therefore smaller amount of sample being analysed. Importantly, the push button functionality of the ImagePrep and its standardised methods make it a viable candidate for clinical application.

Printed IMS arrays are, in effect, whole tissue profiling experiments generated by repeated deposition of picolitre volumes of matrix in a rectangular grid (see Figure 2). Deposition of matrix in this manner limits users to a maximum acquisition of resolution determined by the droplet size on the tissue which can vary from 150-250 $\mu \mathrm{m}$, centre to centre, depending on the quality of the preparation.

Table 5. Summary of reproducibility, acquisition resolution, the advantages and the disadvantages of four different matrix deposition methods are listed here for air brushes and the ImagePrep station (matrix nebulising/spray instruments) as well as the ChIP-1000 and Labcyte Portrait (matrix printing instruments).

\begin{tabular}{|c|c|c|c|c|}
\hline & \multicolumn{2}{|c|}{ Nebulising instruments } & \multicolumn{2}{|c|}{ Printers } \\
\hline & Air brush & ImagePrep station & ChIP-1000 & Labcyte Portrait \\
\hline Reproducibility & Poor & Good & Excellent & Excellent \\
\hline $\begin{array}{l}\text { Acquisition } \\
\text { resolution }\end{array}$ & $\geq 5 \mu \mathrm{m}$ & $\geq 20 \mu \mathrm{m}$ & $\geq 150 \mu \mathrm{m}$ & $\geq 150 \mu \mathrm{m}$ \\
\hline \multirow{3}{*}{ Advantages } & Cheap & Automated & Automated & Automated \\
\hline & $\begin{array}{l}\text { High resolution MS } \\
\text { acquisition }\end{array}$ & $\begin{array}{l}\text { High resolution MS } \\
\text { acquisition }\end{array}$ & $\begin{array}{c}\text { Control over } \\
\text { reagent volume } \\
\text { deposited }\end{array}$ & $\begin{array}{l}\text { Control over reagent } \\
\text { volume deposited }\end{array}$ \\
\hline & $\begin{array}{c}\text { Good for start up } \\
\text { imaging MS } \\
\text { laboratories }\end{array}$ & $\begin{array}{c}\text { Default methods } \\
\text { available but methods } \\
\text { can be modified by user }\end{array}$ & High MS sensitivity & High MS sensitivity \\
\hline \multirow{3}{*}{ Disadvantages } & $\begin{array}{c}\text { Lower } \\
\text { peptide/protein } \\
\text { incorporation into } \\
\text { matrix } \\
\end{array}$ & $\begin{array}{l}\text { Lower peptide/protein } \\
\text { incorporation into matrix }\end{array}$ & Expensive & Most expensive \\
\hline & $\begin{array}{c}\text { Requires } \\
\text { experienced user }\end{array}$ & $\begin{array}{c}\text { Requires experienced } \\
\text { user }\end{array}$ & $\begin{array}{c}\text { Time consuming } \\
\text { preparation }\end{array}$ & $\begin{array}{c}\text { Time consuming } \\
\text { preparation }\end{array}$ \\
\hline & Manual preparation & Expensive & $\begin{array}{c}\text { Lower data } \\
\text { acquisition } \\
\text { resolution than } \\
\text { nebulised } \\
\text { preparations }\end{array}$ & $\begin{array}{l}\text { Lower data } \\
\text { acquisition } \\
\text { resolution than } \\
\text { nebulised } \\
\text { preparations }\end{array}$ \\
\hline
\end{tabular}

The ChIP-1000, for example, uses a pressure manifold to maintain solution in a reservoir mounted on top of a $55 \mu \mathrm{m}$ printing nozzle. Droplets ranging from 100-200 pL are ejected using force generated by current flow through a piezo electric material. The principal down side to the ChIP-1000 is the nozzle itself, which can clog with crystallised matrix. In terms of printing, DHB is the most stable ChIP-1000 matrix. Because DHB is water soluble, and water is not as volatile as organic solvents, printing can be performed for hours without direct supervision. However, several solid ionic 
matrixes (e.g., CHCA with molar excess of aniline, see Table 4) have been developed that increase print stability by reducing the rate of CHCA and SA crystallisation [61]. The gold standard for printed arrays is a nozzle free system such as the Labcyte Portrait printer, which focuses sound waves at the surface of a matrix solution. Turbulence at the surface ejects droplets (of similar size to the ChIP-1000) vertically onto the tissue section which is suspended, face down, above the solution tray [59]. The high cost of this instrument and methods to overcome matrix clogging issues on the ChIP-1000 have unfortunately prevented widespread application of the Portrait.

As already discussed, there is a balance between sensitivity and spatial resolution. Because the volume of matrix deposited is greater for printers than nebulising instruments, sample extraction efficiency is also greater, leading to improved MS sensitivity. However, for the purposes of a grading approach there is typically no reason to implement the highest resolution nebulised IMS methods, with most studies settling for a 100-200 $\mu \mathrm{m}$ spatial resolution [39]. Moreover, deposition of printed arrays or singular spots onto a tumour section, whether guided by histology or independent of it, is more than sufficient to generate MS profiles for grading and biomarker detection [28,30,62].

\section{Peptide Imaging Provides Data Complementary to Protein Imaging}

Despite advances such as HFIP solvent for improved protein extraction, for the moment, IMS is limited to masses below $70 \mathrm{kDa}$ [31], preventing ready detection of higher molecular weight proteins such as cell surface receptors. Moreover, MS sensitivity decreases dramatically as protein mass increases. Consequently, only the very highest abundance high molecular weight proteins will be observed. To circumvent these issues, it is possible to perform in situ proteolytic digests by deposition of enzymes such as trypsin. The digested tissue is coated with matrix (homogeneous layer or printed array) and MALDI-TOF MS acquisition is performed in the peptide mass range (0-6 kDa, see Figure 1). The resulting peptide MS spectra (Figure 3c) are vastly more complex than the protein level (Figure 3a). However, digest methods allow (i) higher molecular weight proteins to be analysed via their component peptides, (ii) fragmentation of highly abundant peptides directly from tissue to gain sequence information [63] and (iii) direct extraction from the tissue and identification using LC-MS methods, which are well established in most proteomics facilities [64].

\section{Using Histology to Guide Imaging Mass Spectrometry}

After MS acquisition is complete, the matrix crystals can be removed using ethanol to allow histological staining and assessment by a pathologist. MS compatible stains such as cresyl violet can also be used prior to IMS to guide analyses [47,48]. Importantly, good correlation between MS ion intensity maps and anatomical structures has been demonstrated previously for various tissues including neuroendocrine [65], breast [39] and ovarian cancer (see Figure 3d) [64]. This correlation shows the value of IMS as a complement to histology.

The ability to correlate histology and IMS data was exploited recently for investigation of the changing molecular profile of tumour interfaces. Upon analysis of the tumour boundaries of renal cell carcinoma, the definition of "normal" surrounding tissue has been called into question, with demonstration of potential tumour associated protein changes appearing well past the histological tumour margin [66]. In a separate study on serous ovarian carcinomas, IMS was used to show that the 
tumour interface zone contains a unique set of MS detectable masses as compared to tumour and surrounding normal tissue [29]. IMS can thus generate molecular data which is unique and novel to that provided by morphology alone.

\section{Ovarian Cancer Biomarker Discovery Using Imaging Mass Spectrometry}

In developing the IMS technology, preliminary IMS biomarker discovery projects for ovarian cancer have been reported by the same group that presented profiling work on ovarian carcinomas (see Section 7). Putative biomarkers of ovarian cancer were detected using printed IMS arrays and subsequently identified using LC-MS/MS of digested cancerous tissue [30]. These included 11S proteasome activator complex Reg Alpha fragment [28], oviductin (mucin-9) [30] and orosomucoid [30], the roles of which are described briefly here. Reg-Alpha, or PA28, is an antigen processing protein, an increased expression of which may allow presentation of self peptides on tumour cells, and subsequently immune evasion [28,30]. Oviductin is a marker of oviductal epithelium and tubal differentiation marker [30,67], and finally orosomucoid is an acute phase protein previously evaluated as a marker of ovarian cancer and possible immune suppressor through action on $\mathrm{T}$ lymphocytes $[30,68]$. It is clear that relevant markers of disease can be identified. However, more work is required to determine how effectively MS profiles of such markers can distinguish the subtypes of ovarian cancer and how well these markers translate to cancer detection and screening.

Figure 4. MALDI-TOF mass spectrometry profiles of ovarian carcinoma and benign tissue sections (a). The individual profiles of three carcinomas and three benign tumour sections are shown in (c), with the mass at $9744.8 \mathrm{~m} / \mathrm{z}$ highlighted as the potential biomarker $11 \mathrm{~S}$ proteasome activator complex Reg Alpha fragment. Figure reprinted, with permission, from Lemaire et al. (2007) [28].

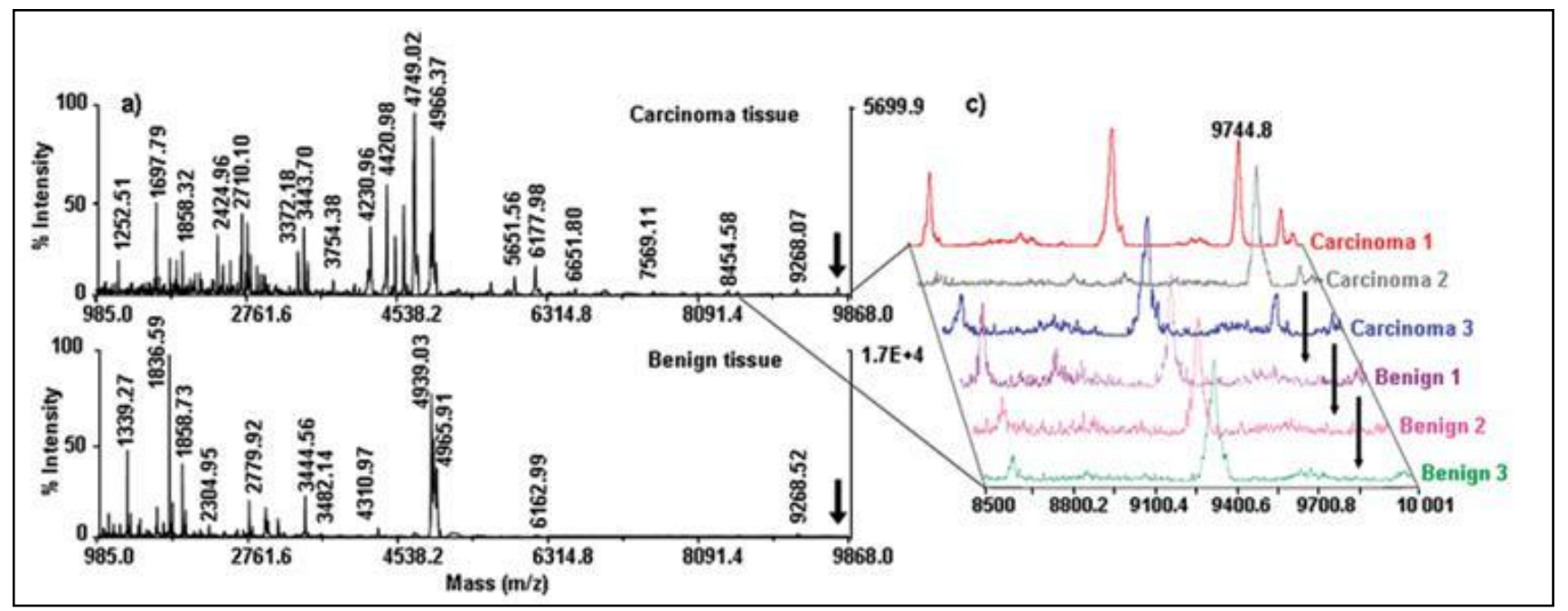

\section{Application of Tryptic Digestion to Formalin-Fixed Paraffin Embedded Ovarian Tissues}

Frozen tissue represents the current gold standard for IMS, given that a freshly preserved tissue will harbor a freshly preserved proteome, which is easy to access using standard methods for both protein and tryptic peptide IMS (see Figure 3). However, the limited archival life of frozen tissue (maximum 
two years for proteomics applications) has forced researchers to adopt methods for accessing peptide and protein mass data in formalin-fixed paraffin embedded (FFPE) tissue; the current global standard for long term tissue preservation in medical centres and research laboratories worldwide [69-71]. However, formalin fixation induces cross-linking between multiple amino acid side chains, creating a linked protein network [72]. To access these tissues by MS, antigen retrieval (AR) [62,64] and/or in situ tryptic digestion [73,74] are required. While AR is not completely understood, its most likely effects are to partially hydrolyse cross-links and denature linked proteins. Typically, this is insufficient for subsequent MS acquisition of the same quality as frozen tissue, because the cross-linking is not reversed completely. Thus, AR is usually followed by tryptic digestion [62].

Figure 5. MALDI-TOF IMS of formalin-fixed paraffin-embedded (FFPE, top row) and frozen (bottom row) ovarian carcinoma. FFPE sections were treated with antigen retrieval. Frozen sections were washed using a previously described protocol. Both sections were digested with trypsin and coated with CHCA matrix using an ImagePrep station. Figure reprinted, with permission, from Gustafsson et al. 2010 [64]. Scale bars $=2 \mathrm{~mm}$.

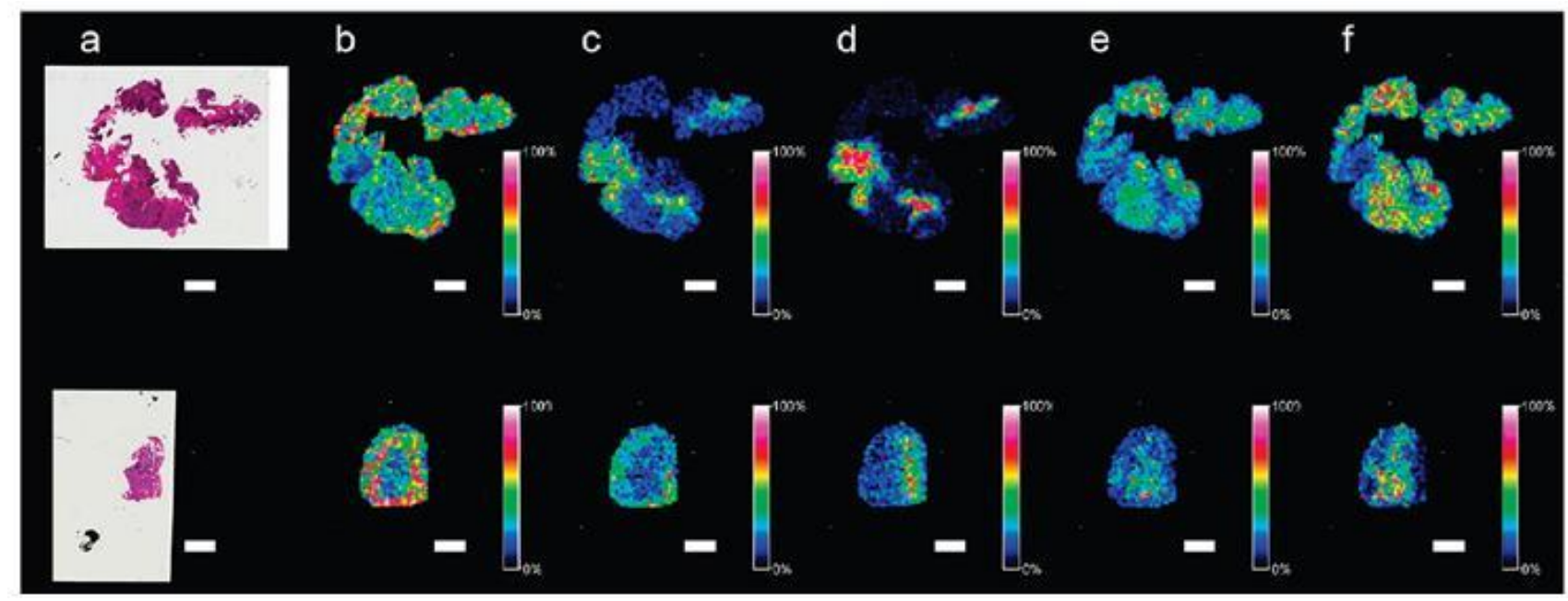

Several publications have so far demonstrated successful application of AR methods for IMS on various tissues [62,74,75], including FFPE ovarian cancer [64,73]. A 2007 study applying tryptic digestion alone to de-paraffinised and rehydrated sections of ovarian cancer showed that many high abundance proteins could be identified directly from tissue [73]. However, this study was a proof of principle application and as such did not demonstrate disease specific distribution of peptides generated from the tissue sections. Our own group has successfully applied citric acid antigen retrieval to ovarian cancer for tryptic peptide IMS (see Figure 5). Peptides were also extracted from in situ proteolytic digests and identified using liquid phase peptide separation and MS. Using this method it was possible to assign tentative identities to 48 individual peptides [64]. Because of the ability to rapidly extract and identify peptides directly from tissue using "classical" fractionation-based proteomics, the translation from peptide IMS data to peptide identification and subsequent in situ validation by IHC becomes less labour intensive. Furthermore, the large existing archives of FFPE ovarian tissue will allow any acquired peptide IMS data to be matched to patient history and clinical outcome. 


\section{Conclusions and Future Prospects}

The successful application of MS profiling and IMS for tissue classification and grading has been demonstrated for different types of cancer. In the case of ovarian cancer, preliminary studies have isolated and identified potential tissue specific peptide and proteins masses using IMS. The current aim is continued application of in situ MS methods to demonstrate acquisition of ovarian cancer grade and/or subtype specific protein/peptide profiles from both frozen and archived FFPE tissues. Importantly, from further investigation, IMS derived markers could be used to track molecular changes across ovarian tumours as well as their interfaces with normal tissue to determine the importance of subsequent protein and peptide masses as tissue markers. Following selection of these specific markers, identification, as already demonstrated in several publications, can be achieved using classical proteomics at either the protein or peptide level (fractionation/identification methods such as LC-MS). Subsequent validation of these masses using IHC will ultimately indicate the suitability of masses for further development as diagnostic markers for ovarian cancer sub-type or grade and for validation in large patient cohorts as biomarkers.

\section{References}

1. Hennessy, B.T.; Coleman, R.L.; Markman, M. Ovarian cancer. Lancet 2009, 374, 1371-1382.

2. Menon, U.; Gentry-Maharaj, A.; Hallett, R.; Ryan, A.; Burnell, M.; Sharma, A.; Lewis, S.; Davies, S.; Philpott, S.; Lopes, A.; Godfrey, K.; Oram, D.; Herod, J.; Williamson, K.; Seif, M.W.; Scott, I.; Mould, T.; Woolas, R.; Murdoch, J.; Dobbs, S.; Amso, N.N.; Leeson, S.; Cruickshank, D.; McGuire, A.; Campbell, S.; Fallowfield, L.; Singh, N.; Dawnay, A.; Skates, S.J.; Parmar, M.; Jacobs, I. Sensitivity and specificity of multimodal and ultrasound screening for ovarian cancer, and stage distribution of detected cancers: Results of the prevalence screen of the UK Collaborative Trial of Ovarian Cancer Screening (UKCTOCS). Lancet Oncol. 2009, 10, 327-340.

3. Moore, R.G.; MacLaughlan, S.; Bast, R.C., Jr. Current state of biomarker development for clinical application in epithelial ovarian cancer. Gynecol. Oncol. 2010, 116, 240-245.

4. Mor, G.; Visintin, I.; Lai, Y.; Zhao, H.; Schwartz, P.; Rutherford, T.; Yue, L.; Bray-Ward, P.; Ward, D.C. Serum protein markers for early detection of ovarian cancer. Proc. Natl. Acad. Sci. USA 2005, 102, 7677-7682..

5. Muller, C.Y. Doctor, should I get this new ovarian cancer test-OVA1? Obstet. Gynecol. 2010, 116, 246-247.

6. Anderson, N.L.; Anderson, N.G. The human plasma proteome: History, character, and diagnostic prospects. Mol. Cell Proteomics 2002, 1, 845-867.

7. Poschmann, G.; Sitek, B.; Sipos, B.; Hamacher, M.; Vonend, O.; Meyer, H.E.; Stuhler, K. Cell-based proteome analysis: The first stage in the pipeline for biomarker discovery. Biochim. Biophys. Acta 2009, 1794, 1309-1316.

8. Eriksson, J.; Fenyo, D. Improving the success rate of proteome analysis by modeling protein-abundance distributions and experimental designs. Nat. Biotechnol. 2007, 25, 651-655.

9. Cancer of the ovary-SEER stat fact sheets. Surveillance Epidemiology and End Results. Available online: http://seer.cancer.gov/statfacts/html/ovary.html (accessed on 17 January 2010). 
10. Benedet, J.L.; Bender, H.; Jones, H., III; Ngan, H.Y.; Pecorelli, S. FIGO staging classifications and clinical practice guidelines in the management of gynecologic cancers. FIGO Committee on Gynecologic Oncology. Int. J. Gynaecol. Obstet. 2000, 70, 209-262.

11. Kosary, C.L. FIGO stage, histology, histologic grade, age and race as prognostic factors in determining survival for cancers of the female gynecological system: An analysis of 1973-1987 SEER cases of cancers of the endometrium, cervix, ovary, vulva, and vagina. Semin. Surg. Oncol. 1994, 10, 31-46.

12. Shimizu, Y.; Kamoi, S.; Amada, S.; Akiyama, F.; Silverberg, S.G. Toward the development of a universal grading system for ovarian epithelial carcinoma: Testing of a proposed system in a series of 461 patients with uniform treatment and follow-up. Cancer 1998, 82, 893-901.

13. Sagae, S.; Saito, T.; Satoh, M.; Ikeda, T.; Kimura, S.; Mori, M.; Sato, N.; Kudo, R. The reproducibility of a binary tumor grading system for uterine endometrial endometrioid carcinoma, compared with FIGO system and nuclear grading. Oncology 2004, 67, 344-350.

14. Vang, R.; Shih Ie, M.; Kurman, R.J. Ovarian low-grade and high-grade serous carcinoma: Pathogenesis, clinicopathologic and molecular biologic features, and diagnostic problems. Adv. Anat. Pathol. 2009, 16, 267-282.

15. Ali-Fehmi, R.; Semaan, A.; Sethi, S.; Arabi, H.; Bandyopadhyay, S.; Hussein, Y.R.; Diamond, M.P.; Saed, G.; Morris, R.T.; Munkarah, A.R. Molecular typing of epithelial ovarian carcinomas using inflammatory markers. Cancer 2010, doi:10.1002/cncr.25588.

16. Cho, K.R. Ovarian cancer update: Lessons from morphology, molecules, and mice. Arch. Pathol. Lab. Med. 2009, 133, 1775-1781.

17. Lu, P.; Vogel, C.; Wang, R.; Yao, X.; Marcotte, E.M. Absolute protein expression profiling estimates the relative contributions of transcriptional and translational regulation. Nat. Biotechnol. 2007, 25, 117-124.

18. Gygi, S.P.; Rochon, Y.; Franza, B.R.; Aebersold, R. Correlation between protein and mRNA abundance in yeast. Mol. Cell Biol. 1999, 19, 1720-1730.

19. Kim, H.; Wu, R.; Cho, K.R.; Thomas, D.G.; Gossner, G.; Liu, J.R.; Giordano, T.J.; Shedden, K.A.; Misek, D.E.; Lubman, D.M. Comparative proteomic analysis of low stage and high stage endometrioid ovarian adenocarcinomas. Proteomics Clin. Appl. 2008, 2, 571-584.

20. Washburn, M.P.; Wolters, D.; Yates, J.R., III. Large-scale analysis of the yeast proteome by multidimensional protein identification technology. Nat. Biotechnol. 2001, 19, 242-247.

21. Wilkins, M.R.; Pasquali, C.; Appel, R.D.; Ou, K.; Golaz, O.; Sanchez, J.C.; Yan, J.X.; Gooley, A.A.; Hughes, G.; Humphery-Smith, I.; Williams, K.L.; Hochstrasser, D.F. From proteins to proteomes: Large scale protein identification by two-dimensional electrophoresis and amino acid analysis. Biotechnology 1996, 14, 61-65.

22. Mitulovic, G.; Mechtler, K. HPLC techniques for proteomics analysis - a short overview of latest developments. Brief. Funct. Genomic Proteomic 2006, 5, 249-260.

23. Condina, M.R.; Gustafsson, J.O.; Klingler-Hoffmann, M.; Bagley, C.J.; McColl, S.R.; Hoffmann, P., EZYprep LC-coupled MALDI-TOF/TOF MS: An improved matrix spray application for phosphopeptide characterisation. Proteomics 2010, 10, 2516-2530.

24. Zhu, Y.; Wu, R.; Sangha, N.; Yoo, C.; Cho, K.R.; Shedden, K.A.; Katabuchi, H.; Lubman, D.M. Classifications of ovarian cancer tissues by proteomic patterns. Proteomics 2006, 6, 5846-5856. 
25. Caprioli, R.M.; Farmer, T.B.; Gile, J. Molecular imaging of biological samples: Localization of peptides and proteins using MALDI-TOF MS. Anal. Chem. 1997, 69, 4751-4760.

26. Amstalden van Hove, E.R.; Smith, D.F.; Heeren, R.M. A concise review of mass spectrometry imaging. J. Chromatogr. A 2010, 1217, 3946-3954.

27. Meriaux, C.; Franck, J.; Wisztorski, M.; Salzet, M.; Fournier, I. Liquid ionic matrixes for MALDI mass spectrometry imaging of lipids. J. proteomics 2010, 73, 1204-1218.

28. Lemaire, R.; Menguellet, S.A.; Stauber, J.; Marchaudon, V.; Lucot, J.P.; Collinet, P.; Farine, M.O.; Vinatier, D.; Day, R.; Ducoroy, P.; Salzet, M.; Fournier, I. Specific MALDI imaging and profiling for biomarker hunting and validation: Fragment of the $11 \mathrm{~S}$ proteasome activator complex, Reg alpha fragment, is a new potential ovary cancer biomarker. J. Proteome Res. 2007, 6, 4127-4134.

29. Kang, S.; Shim, H.S.; Lee, J.S.; Kim, D.S.; Kim, H.Y.; Hong, S.H.; Kim, P.S.; Yoon, J.H.; Cho, N.H. Molecular proteomics imaging of tumor interfaces by mass spectrometry. J. Proteome Res. 2010, 9, 1157-1164.

30. El Ayed, M.; Bonnel, D.; Longuespee, R.; Castelier, C.; Franck, J.; Vergara, D.; Desmons, A.; Tasiemski, A.; Kenani, A.; Vinatier, D.; Day, R.; Fournier, I.; Salzet, M. MALDI imaging mass spectrometry in ovarian cancer for tracking, identifying, and validating biomarkers. Med. Sci. Monit. 2010, 16, BR233-BR245.

31. Franck, J.; Longuespee, R.; Wisztorski, M.; van Remoortere, A.; van Zeijl, R.; Deelder, A.; Salzet, M.; McDonnell, L.; Fournier, I. MALDI mass spectrometry imaging of proteins exceeding 30,000 daltons. Med. Sci. Monit. 2010, 16, BR293-BR299.

32. Karas, M.; Gluckmann, M.; Schafer, J. Ionization in matrix-assisted laser desorption/ionization: Singly charged molecular ions are the lucky survivors. J. Mass Spectrom. 2000, 35, 1-12.

33. Knochenmuss, R.; Zenobi, R. MALDI ionization: The role of in-plume processes. Chem. Rev. 2003, 103, 441-452.

34. Knochenmuss, R. Ion formation mechanisms in UV-MALDI. Analyst 2006, 131, 966-986.

35. Daltonics, B. MALDI Theory Mass Spectrometry; Bruker Daltonics: Bremen, Germany, 2004; p. 18.

36. Reyzer, M.L.; Hsieh, Y.; Ng, K.; Korfmacher, W.A.; Caprioli, R.M. Direct analysis of drug candidates in tissue by matrix-assisted laser desorption/ionization mass spectrometry. J. Mass. Spectrom. 2003, 38, 1081-1092.

37. Chen, R.; Hui, L.; Sturm, R.M.; Li, L. Three dimensional mapping of neuropeptides and lipids in crustacean brain by mass spectral imaging. J. Am. Soc. Mass. Spectrom. 2009, 20, 1068-1077.

38. Taban, I.M.; Altelaar, A.F.; Van der Burgt, Y.E.; McDonnell, L.A.; Heeren, R.M.; Fuchser, J.; Baykut, G. Imaging of peptides in the rat brain using MALDI-FTICR mass spectrometry. J. Am. Soc. Mass. Spectrom. 2007, 18, 145-151.

39. Rauser, S.; Marquardt, C.; Balluff, B.; Deininger, S.O.; Albers, C.; Belau, E.; Hartmer, R.; Suckau, D.; Specht, K.; Ebert, M.P.; Schmitt, M.; Aubele, M.; Hofler, H.; Walch, A. Classification of HER2 receptor status in breast cancer tissues by MALDI imaging mass spectrometry. J. Proteome Res .2010, 9, 1854-1863.

40. Gustafsson, J.O.R.; McColl, S.R.; Hoffmann, P. Imaging mass spectrometry and its methodological application to Murine tissue. J. Proteomics Bioinformatics 2008, 1, 458-463. 
41. Lemaire, R.; Wisztorski, M.; Desmons, A.; Tabet, J.C.; Day, R.; Salzet, M.; Fournier, I. MALDI-MS direct tissue analysis of proteins: Improving signal sensitivity using organic treatments. Anal. Chem. 2006, 78, 7145-7153.

42. Seeley, E.H.; Oppenheimer, S.R.; Mi, D.; Chaurand, P.; Caprioli, R.M. Enhancement of protein sensitivity for MALDI imaging mass spectrometry after chemical treatment of tissue sections. J. Am. Soc. Mass. Spectrom. 2008, 19, 1069-1077.

43. Schwartz, S.A.; Reyzer, M.L.; Caprioli, R.M. Direct tissue analysis using matrix-assisted laser desorption/ionization mass spectrometry: Practical aspects of sample preparation. J. Mass. Spectrom. 2003, 38, 699-708.

44. Chaurand, P.; Norris, J.L.; Cornett, D.S.; Mobley, J.A.; Caprioli, R.M. New developments in profiling and imaging of proteins from tissue sections by MALDI mass spectrometry. J. Proteome Res. 2006, 5, 2889-2900.

45. Ilina, E.N.; Borovskaya, A.D.; Malakhova, M.M.; Vereshchagin, V.A.; Kubanova, A.A.; Kruglov, A.N.; Svistunova, T.S.; Gazarian, A.O.; Maier, T.; Kostrzewa, M.; Govorun, V.M. Direct bacterial profiling by matrix-assisted laser desorption-ionization time-of-flight mass spectrometry for identification of pathogenic Neisseria. J. Mol. Diagn. 2009, 11, 75-86.

46. Yanagisawa, K.; Shyr, Y.; Xu, B.J.; Massion, P.P.; Larsen, P.H.; White, B.C.; Roberts, J.R.; Edgerton, M.; Gonzalez, A.; Nadaf, S.; Moore, J.H.; Caprioli, R.M.; Carbone, D.P. Proteomic patterns of tumour subsets in non-small-cell lung cancer. Lancet 2003, 362, 433-439.

47. Caldwell, R.L.; Holt, G.E.; Caprioli, R.M. Tissue profiling by MALDI mass spectrometry distinguishes clinical grades of soft tissue sarcomas. Cancer Genomics Proteomics 2005, 2, 333-346.

48. Chaurand, P.; Schwartz, S.A.; Billheimer, D.; Xu, B.J.; Crecelius, A.; Caprioli, R.M. Integrating histology and imaging mass spectrometry. Anal. Chem. 2004, 76, 1145-1155.

49. Samsi, S.S.; Krishnamurthy, A.K.; Groseclose, M.; Caprioli, R.M.; Lozanski, G.; Gurcan, M.N. Imaging mass spectrometry analysis for follicular lymphoma grading. Conf. Proc. IEEE Eng. Med. Biol. Soc. 2009, 2009, 6969-6972.

50. Rahman, S.M.; Shyr, Y.; Yildiz, P.B.; Gonzalez, A.L.; Li, H.; Zhang, X.; Chaurand, P.; Yanagisawa, K.; Slovis, B.S.; Miller, R.F.; Ninan, M.; Miller, Y.E.; Franklin, W.A.; Caprioli, R.M.; Carbone, D.P.; Massion, P.P. Proteomic patterns of preinvasive bronchial lesions. Am. J. Respir. Crit. Care Med. 2005, 172, 1556-1562.

51. Schwamborn, K.; Krieg, R.C.; Reska, M.; Jakse, G.; Knuechel, R.; Wellmann, A. Identifying prostate carcinoma by MALDI-Imaging. Int. J. Mol. Med. 2007, 20, 155-159.

52. Cazares, L.H.; Troyer, D.; Mendrinos, S.; Lance, R.A.; Nyalwidhe, J.O.; Beydoun, H.A.; Clements, M.A.; Drake, R.R.; Semmes, O.J. Imaging mass spectrometry of a specific fragment of mitogen-activated protein kinase/extracellular signal-regulated kinase kinase kinase 2 discriminates cancer from uninvolved prostate tissue. Clin. Cancer Res. 2009, 15, 5541-5551.

53. Agar, N.Y.; Malcolm, J.G.; Mohan, V.; Yang, H.W.; Johnson, M.D.; Tannenbaum, A.; Agar, J.N.; Black, P.M. Imaging of meningioma progression by matrix-assisted laser desorption ionization time-of-flight mass spectrometry. Anal. Chem. 2010, 82, 2621-2625. 
54. Schwartz, S.A.; Weil, R.J.; Thompson, R.C.; Shyr, Y.; Moore, J.H.; Toms, S.A.; Johnson, M.D.; Caprioli, R.M. Proteomic-based prognosis of brain tumor patients using direct-tissue matrixassisted laser desorption ionization mass spectrometry. Cancer Res. 2005, 65, 7674-7681.

55. Rompp, A.; Guenther, S.; Schober, Y.; Schulz, O.; Takats, Z.; Kummer, W.; Spengler, B. Histology by mass spectrometry: Label-free tissue characterization obtained from high-accuracy bioanalytical imaging. Angew. Chem. Int. Ed. Engl. 2010, 49, 3834-3838.

56. Jardin-Mathe, O.; Bonnel, D.; Franck, J.; Wisztorski, M.; Macagno, E.; Fournier, I.; Salzet, M. MITICS (MALDI Imaging Team Imaging Computing System): A new open source mass spectrometry imaging software. J. Proteomics 2008, 71, 332-345.

57. Martens, L.; Chambers, M.; Sturm, M.; Kessner, D.; Levander, F.; Shofstahl, J.; Tang, W.H.; Rompp, A.; Neumann, S.; Pizarro, A.D.; Montecchi-Palazzi, L.; Tasman, N.; Coleman, M.; Reisinger, F.; Souda, P.; Hermjakob, H.; Binz, P.A.; Deutsch, E.W. mzML-a community standard for mass spectrometry data. Mol. Cell Proteomics 2010, doi:10.1074/mcp.R110.000133.

58. Rompp, A.; Schramm, T.; Hester, A.; Klinkert, I.; Both, J.P.; Heeren, R.M.; Stockli, M.; Spengler, B. imzML: Imaging mass spectrometry markup language: A common data format for mass spectrometry imaging. Methods Mol. Biol. 2011, 696, 205-224.

59. Aerni, H.R.; Cornett, D.S.; Caprioli, R.M. Automated acoustic matrix deposition for MALDI sample preparation. Anal. Chem. 2006, 78, 827-834.

60. Franck, J.; Arafah, K.; Barnes, A.; Wisztorski, M.; Salzet, M.; Fournier, I. Improving tissue preparation for matrix-assisted laser desorption ionization mass spectrometry imaging. Part 1: Using microspotting. Anal. Chem. 2009, 81, 8193-8202.

61. Lemaire, R.; Tabet, J.C.; Ducoroy, P.; Hendra, J.B.; Salzet, M.; Fournier, I. Solid ionic matrixes for direct tissue analysis and MALDI imaging. Anal. Chem. 2006, 78, 809-819.

62. Groseclose, M.R.; Massion, P.P.; Chaurand, P.; Caprioli, R.M. High-throughput proteomic analysis of formalin-fixed paraffin-embedded tissue microarrays using MALDI imaging mass spectrometry. Proteomics 2008, 8, 3715-3724.

63. Groseclose, M.R.; Andersson, M.; Hardesty, W.M.; Caprioli, R.M. Identification of proteins directly from tissue: In situ tryptic digestions coupled with imaging mass spectrometry. J. Mass. Spectrom. 2007, 42, 254-262.

64. Gustafsson, J.O.; Oehler, M.K.; McColl, S.R.; Hoffmann, P. Citric acid antigen retrieval (CAAR) for tryptic peptide imaging directly on archived formalin-fixed paraffin-embedded tissue. J. Proteome Res. 2010, 9, 4315-4328.

65. Alexandrov, T.; Becker, M.; Deininger, S.O.; Ernst, G.; Wehder, L.; Grasmair, M.; Von Eggeling, F.; Thiele, H.; Maass, P. Spatial segmentation of imaging mass spectrometry data with edge-preserving image denoising and clustering. J. Proteome Res. 2010, 9, 6535-6546.

66. Oppenheimer, S.R.; Mi, D.; Sanders, M.E.; Caprioli, R.M. Molecular analysis of tumor margins by MALDI mass spectrometry in renal carcinoma. J. Proteome Res. 2010, 9, 2182-2190.

67. Woo, M.M.; Alkushi, A.; Verhage, H.G.; Magliocco, A.M.; Leung, P.C.; Gilks, C.B.; Auersperg, N. Gain of OGP, an estrogen-regulated oviduct-specific glycoprotein, is associated with the development of endometrial hyperplasia and endometrial cancer. Clin. Cancer Res. 2004, 10, 7958-7964. 
68. Elg, S.A.; Mayer, A.R.; Carson, L.F.; Twiggs, L.B.; Hill, R.B.; Ramakrishnan, S. Alpha-1 acid glycoprotein is an immunosuppressive factor found in ascites from ovaria carcinoma. Cancer 1997, 80, 1448-1456.

69. Addis, M.F.; Tanca, A.; Pagnozzi, D.; Crobu, S.; Fanciulli, G.; Cossu-Rocca, P.; Uzzau, S. Generation of high-quality protein extracts from formalin-fixed, paraffin-embedded tissues. Proteomics 2009, 9, 3815-3823.

70. Addis, M.F.; Tanca, A.; Pagnozzi, D.; Rocca, S.; Uzzau, S. 2-D PAGE and MS analysis of proteins from formalin-fixed, paraffin-embedded tissues. Proteomics 2009, 9, 4329-4339.

71. Grantzdorffer, I.; Yumlu, S.; Gioeva, Z.; von Wasielewski, R.; Ebert, M.P.; Rocken, C. Comparison of different tissue sampling methods for protein extraction from formalin-fixed and paraffin-embedded tissue specimens. Exp. Mol. Pathol. 2010, 88, 190-196.

72. Hood, B.L.; Conrads, T.P.; Veenstra, T.D. Mass spectrometric analysis of formalin-fixed paraffin-embedded tissue: Unlocking the proteome within. Proteomics 2006, 6, 4106-4114.

73. Aoki, Y.; Toyama, A.; Shimada, T.; Sugita, T.; Aoki, C.; Umino, Y.; Suzuki, A.; Aoki, D.; Daigo, Y.; Nakamura, Y.; Sato, T.A. A novel method for analyzing formalin-fixed paraffin embedded (FFPE) tissue sections by mass spectrometry imaging. Proc. Jpn. Acad. Ser. 2007, 83, 205-214.

74. Lemaire, R.; Desmons, A.; Tabet, J.C.; Day, R.; Salzet, M.; Fournier, I. Direct analysis and MALDI imaging of formalin-fixed, paraffin-embedded tissue sections. J. Proteome Res. 2007, 6, 1295-1305.

75. Stauber, J.; Lemaire, R.; Franck, J.; Bonnel, D.; Croix, D.; Day, R.; Wisztorski, M.; Fournier, I.; Salzet, M. MALDI imaging of formalin-fixed paraffin-embedded tissues: Application to model animals of parkinson disease for biomarker hunting. J. Proteome Res. 2008, 7, 969-978.

(C) 2011 by the authors; licensee MDPI, Basel, Switzerland. This article is an open access article distributed under the terms and conditions of the Creative Commons Attribution license (http://creativecommons.org/licenses/by/3.0/). 